УДК 343.131

\author{
Ю. П. Аленін, В. К. Волошина
}

\title{
ПОНЯТТЯ ТА СИСТЕМА ПРИНЦИПІВ КРИМІНАЛЬНОГО ПРОВАЛЖЕННЯ
}

Кожна галузь права, включаючи й кримінальне процесуальне право, грунтується на певних положеннях, принципах, які визначають їі сутність і зміст найважливіших інститутів і норм. Разом із тим у юридичній літературі існують різні підходи стосовно такого важливого питання, як визначення поняття приншипу кримінального процесу.

У теорії кримінального пропесу до проб̆лематики принципів кримінального процесу зверталася значна кількість дослідників. Низку наукових праць присвятили загальним питанням поняття та системи принципів кримінального процесу такі втені, як: Н. В. Агутіна, В. П. Божьєв, А. В. Гріненко, Ю. М. Грошевий, Т. М. Добровольська, З. Д. Єнікеєв, В. Т. Маляренко, Т. М. Мірошніченко, М. М. Михеєнко, П. I. Репешко, М. С. Строгович, I. В. Тирічев, В. М. Тертишник, Г. I. Чангулі, Р. Х. Якупов та ін. Після прийняття нового Кримінального процесуального кодексу дане питання висвітлювалось у роботах таких видатних вчених, як О. I. Галаган, Ю. М. Грошевий, О. П. Кучинська, В. Т. Нор, Д. П. Письменний, В. M. Тертишник та ін.

Кримінальний процесуальний кодекс 2012 року містить главу 2, яка присвячена основним засадам кримінального провадження та їх змісту, але не визначає, що саме $\epsilon$ «засадою кримінального провадження». Крім того, дане визначення викликає дискусії серед учених-юристів щодо вживання термінів «принцип» та «засада» [1, с. 34-35]. Актуальним, на нашу думку, залишається питання шодо визначення системи принципів кримінального провадження, аналіз наявних теоретичних розробок вказує на недостатню вивченість цієї пробллеми.

Засада - це вихідне, головне положення, принцип; основа світогляду, правило поведінки [2, с. 325]. Слід зазначити, що слово «принцип», яке прийшло в російську мову (так само, як і в інші слов'янські мови) з латинської, означає «початок», «основи». Відповідно до твердження В. Даля, «принцип - наукова або моральна основа, фундамент, правило, підстава, 
від якого не відступають» [3, с. 431]. У словнику іноземних слів надано таке тлумачення цього слова: «Принцип - [ лат. principium основа, початок] 1) основне вихідне положення якої-небудь теоріі, навчання; 2) внутрішнє переконання, погляд на речі, шо визначають норму поводження; 3) основа устрою, діi якого-небудь механізму, приладу, установки» $[4$, c. 400$]$. Таким чином, ключове семантичне значення терміна «принцип» - це основа, початок певного явища або процесу. У філософському розумінні принципом $\varepsilon$ теоретичне узагальнення найбільш типового, що констатує і виражає закономірність, покладену в основу пізнання взагалі або в основу якої-небудь галузі знання зокрема. Стосовно ж практичної діяльності принцип «означає одне з основних, загальних вимог, якому повинна відповідати дана діяльність» $[5$, с. 44$]$.

Вважаємо за допільне погодитися з вченими-юристами, які ототожнюють поняття «приншип» та «засада» $[6 ; 7 ; 8 ; 9]$.

У наукових дослідженнях із загальної теорії права, виходячи з позиції, що принципи права - це нормативні засади позитивного права, що визначають сутність і спрямованість правового регулювання, зазначається необхідність відмежування їх від більш широкого за обсягом поняття правових принципів (принципів правової свідомості чи јоктрини) - основоположних для права ідей, а також принципів інших соціальних явищ (загальносоціальних принципів) та певних видів юридичної діяльності (принципів правотворчості, правозастосування, тлумачення права, правореалізашіі) $[10$, c. 20]. Таке розмежування може бути застосовано й для розв'язання певних проблем визначення принципу кримінального провадження.

Формулювання поняття «принцип» стосовно сфери кримінального судочинстьа $є$ однією з найбільш важливих теоретичних проблтем, тому що принципи кримінального провадження, по суті, являють собою «..основні положення, які визначають усю систему процесуальних форм, увесь лад процесуальних відносин» $[11$, с. $6 ; 12$, с. 96].

Питанням принципів кримінального процесу в юридичній літературі приділяєТься велика увага. Так, значний внесок у розроб́ку поняття приншипів кримінального судочинства зробив $M$. С. Строгович, який зазначав, шо ними варто вважати найважливіші й визначальні правові положення, на яких побудований кримінальний процес [13, с. 124]. Таке визначення повністю відповідає загальнонауковому поняттю і може бути покладене в основу подальшого аналізу принципів кримінального провадження.

3 урахуванням тієї ролі, яку відіграють принципи в структурі кримінального процесуального права, існує потреба в поฐальшому уточненні ix форм вираження у кримінальному провадженні, тобто у порядку закріплення кримінальних процесуальних принципів у кримінальному процесуальному законодавстві.

Слід зазначити, шо в юридичній літературі сформульовано всілякі дефініції принципів кримінального провадження.

Одні вчені (М. С. Строгович, Ю. П. Янович, О. П. Рижаков, М. О. Громов, В. В. Николайченко, М. Л. Якуб та ін.) під принципами криміналь- 
ного процесу розуміють юридично оформлені керівні положення (правові положення), які закріплюють найбільш загальні й істотні властивості кримінального процесу, шо виражають його природу і сутність

Інші вчені (Ю. М. Грошевий, Л. М. Лобойко, Я. О. Мотовіловкер, В. В. Назаров, Г. М. Омельяненко, В.Т. Нор, А.Л. Ципкін та ін.) трактують принципи кримінального процесу як закріплені у правових нормах положення, що визначають найбільш важливі сторони і напрями діяльності органів досудового розслідування, прокуратури та суду, а також зміст усіх інших норм кримінального процесуального права. Однак із самого змісту терміна «принцип» випливає, шо принципом кримінального провадження може бути визнано не кожне положення, яке характеризує організацію та діяльність органів досудового розслідування, прокуратури та суду. Шоби бути принципом, відповідне положення повинне визначати в організації й діяльності цих органів головні, вихідні моменти, з яких, у свою чергу, випливають положення бі.льш приватного характеру .

Треті (В. М. Тертишник, Л. Б. Ісмаілова, Г. В. Кудрявцева, Ю. Д. Лівшиць, В. В. Навроцька, М. М. Михеєнко та ін.) принципами кримінального процесу називають закріплені в конституційному та процесуальному законодавстві основні ідеї, які визначають побудову кримінального процесу, його сутність і демократизм. Ці визначення принципів кримінального процесу засновані, як уявляється, саме на тому підході до сутності принципу кримінального процесу, відповідно до якого принципом кримінального процесу можна визнати не тільки нормативні положення, але й доктринальні ідеї. Уявляється, формування поняття принципу кримінального провадження через категорію «ідея» $є$ недостатньо обгрунтованим, оскі.льки самі по собі доктринальні ідеї не мають регулятивних властивостей, а стають правовими положеннями у вигляді норм-принципів лише тоді, коли знаходять нормативне закріплення.

Різноманіття дефініцій принципу кримінального провадження, сформульованих протягом тривалого періоду, дозволяє виявити тенденцію, яка склалася ше в радянській кримінально-процесуальній науці і яка проявляється у спробах визначення принципу кримінального провадження, до виявлення тих вимог, критеріїв, яким має відповідати правове положення (або ідея), щоб вважатися принципом кримінального провадження. Цей підхід до визначення сутності принципу уявляється найбільш плідним, оскільки сутність будь-яких правових заходів більш повно можна визначити, виявивши їхні найбі.тьш значимі властивості (критеріi). До такого роду вимог відносили загальний і керівний характер приписів, принципів, ix нормативність, зв'язок із природою і сутністю кримінального процесу та ін.

Загальновизнано, шо для того, шоб окреме правове положення могло вважатися приншипом кримінального провадження, воно має відповідати низці пропонованих до приншипів кримінального процесу вимог. Розглядаючи проблему критеріїв, О. П. Кучинська зазначає, що до них необхідно відносити такі вимоги, як соціальна обумовленість, нормативність, регу- 
лятивність, основоположність, системність, універсальність, непорушність [1; c. 52-56].

M. М. Михеєнко, В. Т. Нор і В. П. Шибіко вважають, шо хоча в юридичній науці й немає єдиного, загальноприйнятого визначення поняття принципу кримінального процесу, але все-таки за всіх розбіжностей точки зору процесуалістів збігаються в основних позиціях. На їхню думку, до критеріїв визначення конкретного положення принципу кримінального процесу варто віднести таку сукупність якостей: 1) це найбільш загальні, вихідні положення, ідеї, які мають фундаментальне значення для кримінального процесу і які визначають його спрямованість, побудову в цілому, форму і зміст стадій та інститутів; 2) принципи відображають пануючі в даній державі політичні та правові ідеї, які стосуються завдань, способу формування і здійснення правосуддя по кримінальних справах; 3) вони мають бути закріплені в нормах права (окремих або декількох); 4) принципи повинні діяти у всіх або декількох стадіях кримінального процесу й обов'язково на його центральній стадії - стадії судового розгляду; 5) порушення якого-небудь принципу означає незаконність рішення у справі та обов'язкове його скасування [14, с. 29]. Цей підхід до визначення критеріїв принципів кримінального провадження $є$ загальноприйнятим $i$ використовується в дослідженнях із розробки загальних проблем принципів кримінального провадження та дослідженні окремих принципів кримінального провадження.

Однак деякі з вишезгаданих критерії не одержали однозначного тлумачення в літературі. Так, наприклад, найважливішою властивістю принципу $\epsilon$ його нормативність: на це неодноразово вказувалося і вказується в юридичній літературі $[15$, с. $33 ; 16$, с. 101]. Однак стосовно способу закріплення принципів у нормах права у науковців немає єдності. Одні вчені визнають як принципи лише ті положення, які одержали своє закріплення в кримінальних процесуальних нормах найбільш загального характеру [17]. Інші вчені відстоюють визначення принципів як основних положень, ідей, шо одержали свого закріплення в законі, незалежно від прийомів i форм їх закріплення, i, крім того, в положеннях, які хоча й не набули безпосереднього вираження в законі, але випливають із низки його норм [18, с. 10-13]. Уяв.ляється, нормативність принципу кримінального процесу може проявлятися як у формулюванні норм-принципів або норм-приписів найбі.льш загального характеру (це норми-принципи), так і виводитися в індуктивний спосіб із різних норм кримінального процесуального закону (це принципи, виведені з норм).

Достатньо дискусійним $є$ такий критерій принципу, як сфера його прояву. Аналіз висловлених у літературі підходів до сфери прояву принципу кримінального процесу дозволяє виявити такі основні тенденції. Думається, не можна обмежувати сферу діяльності принципу ні всіма стадіями кримінального процесу, ні деякими стадіями з обов'язковим проявом у стадії судового розгляду. Кримінальний процес, як і всі інші процеси, відбувається в часі і просторі. Він являє собою систему стадій, що послідовно змі- 
нюють одна одну і мають визначене коло завдань, підсумкових документів, суб'єктів, які беруть у ньому участь. Із загальнонаукової точки зору елементи досліджуваної системи (стадіi) - це різноманітні причинно-наслі.кові зв'язки, шо обумовлюють особливості прояву загальних закономірностей шодо даної «системи параметрів». Тому логічно буде стверджувати, шо певному типу відносин притаманні свої закони, відтворені в уже відомих сутнісних характеристиках-принципах $[19$, с. 54]. Дійсно, багато принципів кримінального процесу знаходять свій прояв в усіх або більшості стадій кримінального процесу, в тому числі у стадії судового розгляду. Однак це не виключає існування тих правових положень, які, не маючи універсального для всього кримінального процесу характеру, відображають сутність, риси, спрямованість конкретної стадіï або провадження як системи стадій (досудового провадження, судового провадження, провадження з перегляду судових рішень). При цьому, безумовно, вони не будуть мати такого ступеня узагальнення, як ті принципи, які поширюють свою дію на всі стадії кримінального процесу, однак будуть мати ключовий характер для визначення сутності та спрямованості, досягнення специфічних завдань конкретної стадії або провадження (наявність яких у літературі ніким не заперечується). Таким чином, при формулюванні поняття і визначенні ознак принципу кримінального провадження необхідно розглядати принцип кримінального провадження як правове положення, яке може реалізовуватися в усіх, декількох або одній процесуальних стадіях.

Таким чином, можна вважати, шо принципами кримінального провадження $\epsilon$ доктринально обгрунтовані основні правові положення, які відображають предмет і метод кримінального процесуального регулювання, демократичну природу кримінального провадження, визначають сутність і структуру його проваджень, стадій та інститутів, спрямовують кримінальну процесуальну діяльність на досягнення завдань, поставлених державою перед, кримінальним судочинством. При цьому критеріями визначення принципів кримінального провадження є: загальнообов'язкова нормативність; доктринальна обгрунтованість; загальний, фундаментальний характер правових положень; спрямованість на досягнення завдань, поставлених державою перед кримінальним судочинством; відбиття предмета й методу кримінального процесуального регулювання; відбиття демократичної природи кримінального процесу; відбиття сутності й структури проваджень, стадій та інститутів кримінального процесу; можливість реалізації в усіх, декількох або одній кримінальній процесуальній стадії; порушення якого-небудь принципу, яке тягне застосування заходів кримінальної процесуальної відповідальності або заходів захисту.

Особливий інтерес у цьому дослідженні спрямований на проблему подальшого розвитку та вдосконалювання системи принципів кримінального провадження. Їх цілісна система вимагає детального дослідження і подальшого розвитку.

Усі принципи кримінального процесу тісно пов'язані між собою, постійно взаємодіють один з одним, зберігаючи при цьому свою власну цінність для 
побудови і ходу процесу. Перебуваючи в тісній взасмодії, жоден із них не суперечить і не перешкоджає виконанню або дотриманню інших. Здійснення положень одних принципів спричиняе необхідність виконання положень принципів інших, i, відповідно, порушення одних тягне порушення інших принципів. У зв'язку із цим можна стверджувати, шо певна кількість принципів не являє собою механічну сукупність правових явищ, а створюється нове правове явище - система принципів кримінального процесу. Система принципів кримінального провадження має об'єктивний характер і являє собою єдину, нерозривну, взаємопов'язану, взаємообумовлену цілісність.

Система принципів кримінального провадження характеризується наявністю підстави для об'єднання іï елементів і специфічних властивостей. Таким чином, підставою для об'єднання певних фундаментальних правових положень у систему принципів кримінального провадження служать завдання кримінального провадження, закріплені ст. 2 КПК Украӥни.

Система принципів через свою повноту і різний зміст складових їі принципів має здатність до збереження своєї цілісності, самовідновлення. Тому порушення якого-небудь принципу не обов'язково паралізуе всю систему, не виключає можливість рішення завдань процесу. Порушення одного принципу кримінального провадження (наприклал, презумпції невинуватості), тягне порушення інших принципів (законності, забезпечення права на захист), однак рівновага системи принципів та іi нормальне функціонування можуть бути відновлені за допомогою інших принципів (наприклад, дією принципу публічності, принципу всебічності, повноти, об'єктивності дослідження обставин кримінального провадження).

Сучасний кримінальний процесуальний закон не передбачає систему принципів кримінального провадження. У ст. 7 КПК законодавець лише перераховує загальні засади (принципи) кримінального провадження.

Питання шодо розмежування принципів також $\epsilon$. јосить дискусійним у кримінальній процесуальній науці. На сьогоднішній день відсутня єдність думок щодо структури та елементів системи принципів кримінального провадження.

Розглядаючи систему принципів, учені, як правило, пов'язують систему принципів з їх класифікацією на певні або обмежуються простим перерахуванням принципів кримінального процесу, які становлять систему його приншипів. Система приншипів кримінального провајження як системно-юридичне утворення має свою структуру.

Структура системи принципів відображає певні взаємозв'язки, взаєморозташування складових частин системи принципів кримінального процесу, ї устрій (будови). При цьому структура системи принципів включає не всі елементи і зв'язки системи принципів кримінального провадження, а лише найбільш істотні компоненти та зв'язки, які мало змінюються при функціонуванні системи приншипів кримінального процесу і забезпечують його існування та зберігають його основні властивості.

Під компонентом системи принципів кримінального процесу розуміється базовий, найпростіший іiі елемент, що $€$ фундаментом іï утворення, тобто принцип кримінального процесу. 
Прототипом формування системи принципів кримінального процесу $є$ класифікація. При шьому за підставами класифікації запропоновано кілька основних класифікацій принципів кримінального процесу. Перша 3 них заснована на побудові системи кримінальних процесуальних принципів на рівні формально-логічних зв'язків шілого і частини. На рівні ших зв'язків принципи кримінального процесу класифікуються на конституційні та інші [20, с. 59-60]; конституційні та спеціальні [21, с. 32]. Класифікація за джерелом закріплення принципу, як і будь-яка інша, має право на існування з урахуванням того, шо виділення конституційних принципів зовсім не означає приниження фундаментального значення інших принципів кримінального процесу, які закріплені в кримінальному процесуальному законодавстві, а не в Конституції. Важливим є зміст певного положення, його значення для побудови та функціонування системи кримінального процесуального права, регульованої ним діяльності суб'єктів кримінального провадження і правовідносин між ними. Таким чином, можна констатувати, що ця класифікація має суто догматичне значення.

Так, Л. М. Лобойко розподі.яє принципи за юридичною силою джерела, в якому їх закріплено, на конституційні (закріплені в Конституції України) та спеціальні (закріплені в інших законах, передусім у КПК). О днак вже характеристика системи принципів кримінального провадження автором була проведена залежно від поширюваності на галузі права, а саме на загальноправові (ті, шо діють у всіх галузях права), міжгалузеві (діють у кількох процесуальних галузях права) та галузеві (діють лише в межах кримінального провадження). Так, до загальноправових принципів він відносить: 1) верховенство права; 2) законність; 3) рівність перед законом і судом; 3) забезпечення права людини на свободу та особисту недоторканність; 4) забезпетення недоторканності житла чи іншого володіння особи; 5) таємниця спілкування; 6) повага до людської гідності; 7) невтручання у приватне життя; 8) недоторканність права власності 9) доступ до правосуддя та обов'язковість судових рішень. До міжгалузевих принципів - 1) змагальність сторін та свобода в поданні ними суду своїх доказів і в доведенні перед судом їх переконливості; 2) безпосередність дослідження показань, речей і документів; 3) диспозитивність; 4) забезпечення права на оскарження процесуальних рішень, дій чи бездіяльності; 5) гласність і відкритість судового провадження та його повне фіксування технічними засобами; 6) принцип розумності строків; 7) принцип мови, якою здійснюється криміна.тьне провадження. Галузевими принципами називає: 1) принцип публіінності; 2) презумпції невинуватості та забезпечення доведеності вини; 3) свобода від самовикриття та право не свідчити проти близьких родичів та членів сім'ї; 4) забезпечення права на захист; 5) заборона двічі притягувати до кримінальної відповідальності за одне й те саме правопорушення $[22$, с. $45-99]$.

В. М. Тертишник виділяє в системі принципів кримінального провадження загальноправові, міжгалузеві та галузеві (кримінально-процесуальні принципи). Окрім зазначених у ст. 7 КПК, він до принципів кримінального 
процесу відносить також: презумпцію добропорядності людини, здійснення правосуддя тільки судом, незалежність суддів, незалежність і процесуальну самостійність слідчого, забезпечення безпеки учасників кримінального процесу, пропорційність, допустимість розгляду справи лише тільки в рамках пред'явленого обвинувачення, свободу оскарження процесуальних дій i рішень, документованість процесу, забезпечення встановлення об'єктивної істини, справедливість, реабілітацію незаконно обвинувачених осіб та осіб, відносно яких мало місце порушення їх прав [16, с. 108-109].

В. Я. Тацій класифікує загальні засади кримінального провадження залежно від ї поширюваності стосовно галузей права на загальноправові, загальнопроцесуальні та кримінальні процесуальні. До загальноправових засад належать: 1) верховенство права; 2) законність; 3) повага до людської гідності; 4) забезпечення права на свободу та особисту недоторканність; 5) недоторканність житла чи іншого володіння особи; 6) таємниця спілкування; 7) невтручання у приватне життя; 8) недоторканність права власності; 9) доступ до правосуддя та обов'язковість судових рішень. До загальнопроцесуальних В. Я. Тацій відносить: 1) рівність перед законом і судом; 2) змагальність сторін та свободу в поданні ними суду своїх доказів і в доведенні перед судом ї переконливості; 3) безпосередність дослідження показань, речей i документів; 4) забезпечення права на оскарження процесуальних рішень, дій чи бездіяльності; 5) диспозитивність; 6) гласність і відкритість судового провадження та його повне фіксування технічними засобами; 7) розумність строків; 8) мова, якою здійснюється кримінальне провадження. До кримінальних процесуальних засад вчений відносить: 1) презумпцію невинуватості та забезпечення доведеності вини; 2) свободу від самовикриття та право не свідчити проти близьких родичів та членів сім'ї; 3) заборону двічі притягувати до кримінальної відповідальності за одне й те саме правопорушення; 4) забезпечення права на захист; 5) публічність $[7$, с. 63].

Досить цікавою, на нашу думку, $є$ система загальних засад, запропонована Ю. М. Грошевим, а саме :

- принципи, що забезпечують захист честі й гідності особи у кримінальному провадженні: повага до людської гідності; забезпечення права на свободу та особисту недоторканність; недоторканність житла чи іншого володіння особи; таємниця спілкування; невтручання у приватне життя; недоторканність права власності; свобода від самовикриття та право не свідчити проти близьких родичів та членів сім'ї; забезпечення права на захист;

- принципи, що забезпечують стабільність кримінальної процесуальної діяльності: верховенство права; рівність перед законом і судом; доступ до правосуддя та обов'язковість судових рішень; забезпечення права на оскарження процесуальних рішень, дій чи бездіяльності; мова, якою здійснюеться кримінальне провадження;

- принципи, що забезпечують законність розшукових начал кримінального провадження: законність; презумпція невинуватості та забезпечення 
доведеності вини; заборона двічі притягувати до кримінальної відповідальності за одне й те саме правопорушення; публлінність; розумність строків;

- принципи, шо забезпечують змагальність кримінального провадження: змагальність сторін та свобода в поданні ними суду своїх доказів і в доведенні перед судом їх переконливості; безпосередність дослідження показань, речей і документів; диспозитивність; гласність і відкритість судового провадження та його повне фіксування технічними засобами $[23$, с. $315-317]$

На нашу думку, найбіпьш прийнятним при конституюванні системи принципів кримінального провадження $є$ використання методів традиційної (формальної) і діалектико-матеріалістичної логіки $[24$, с. 119], а саме побудова системи принципів здійснюеться по тій регульованій сфері суспільних відносин, на які вони поширюються. Ця система використовується й у дослідженнях із загальної теоріі права $[25$, с.171; 26, с. 59].

Таким чином, проаналізувавши праці вчених щодо зазначеного питання, ми дійшли висновку, що систему принципів кримінального провадження складають загальноправові, міжгалузеві, галузеві принципи кримінального провадження та принципи, які властиві досудовому та судовому провадженню.

Однак, окрім засал, зазначених у ст. $7 \mathrm{~K}$ дК, систему принципів бажано доповнити такими принципами, як всебічність, повнота та неупередженість дослідження обставин кримінального провадження $[27$, с. 247], незалежність та недоторканність суддів, здійснення правосуддя тільки судом. Законодавець хоча і не називає їх як окремі засади, але включає до змісту інших принципів, зазначених у розділі $2 \mathrm{~K}$ КК.

Також, на нашу думку, у кримінальному провадженні проявляється такий загальноправовий принцип, як принцип пропорційності. Це нове положення для юридичної літератури, але на нього зверталася увага в роботах таких вчених, як С. Л. Деревянкін, М. I. Козюбра, С. П. Погребняк, В. М. Тертишник, В. Г. Уваров. Принцип пропорційності використовується для визначення меж можливих обмежень прав і свобод людини, для регламенташії повноважень різних органів державної влади та їх збалансування, для запобігання зловживанню дискреційними повноваженнями та встановлення меж свободи розсуду, при вирішенні питань про відповідність злочину і покарання, праці та винагороди за неї тошо [28, с. 54]. Застосування цього принципу в кримінальному провадженні допомагає забезпечити реалізацію завдань кримінального провадження в цілому та завдань окремих стадій кримінального провадження. Так, КПК у розділі 2 передбачає мету та підстави застосування заходів забезпечення кримінального провадження. Метою застосування цих заходів є забезпечення дієвості кримінального провадження, вони носять вик.ючний характер. У ст. 246 КПК передбачено, шо негласні слідчі розшукові діі можуть бути проведені, якшо відомості про злочин та особу, яка його вчинила, неможливо отримати в інший спосіб. Тобто для досягнення завдань кримінального провадження можуть бути застосовані негласні розшукові діiі. Таким чином, принцип пропорцій- 
ності можна визначити як окремий принцип кримінального провадження, згідно з яким мета процесуальних дій має бути суспільно вагомою, а засіб ii досягнення - найменш обтяжливим у конкретних умовах, втручання у сферу прав і свобод людини, застосування заходів забезпечення кримінального провадження, у тому числі запобіжних заходів, може допускатись лише у разі крайньої необхідності, з метою забезпечення ефективної реалізації завдань кримінального провадження, закріплених у ст. 2 КПК, та завдань окремих стадій кримінального провадження.

До загальноправових принципів, які реалізуються в усіх галузях права, у тому числі і в кримінальному процесуальному праві, слід відносити верховенство права, принцип пропорційності, законність, повагу до людської гідності, забезпечення права на свободу та особисту недоторканність; забезпечення недоторканності житла чи іншого володіння особи; таємнишю спілкування; невтручання у приватне життя; нелоторканність права власності; доступ до правосуддя; рівність перед законом і судом.

До міжгалузевих принципів кримінального провадження можна віднести такі, як здійснення правосуддя тільки судом; незалежність суддів i підпорядкування ї тількизакону; всебічність, повнота та неупередженість дослідження обставин кримінального провадження; свобода від самовикриття та право не свідчити проти близьких родичів та членів сім”і; обгрунтованість процесуальних рішень; заборона двічі притягувати до кримінальної відповідальності за одне й те саме правопорушення; обов'язковість судових рішень; забезпечення права на оскарження процесуальних рішень, дій чи бездіяльності; диспозитивність; публічність; змагальність сторін та свобода в поданні ними суду своїх доказів і в доведенні перед судом їх переконливості; розумність строків; мова, якою здійснюється кримінальне провадження; гласність і відкритість судового провадження та його повне фіксування технічними засобами.

Наступна група принципів кримінального провадження - це галузеві, які реалізуються на всіх його стадіях: презумпція невинуватості та забезпечення доведеності вини; забезпечення права на захист.

Також хотілося 6 у системі принципів кримінального провадження визначити принципи, які реалізуються на окремих провадженнях, а саме засади, шо реалізуються в досудовому провадженні: недопустимість розголошення відомостей досудового розслідування; нагляд прокурора, відомчий та судовий контроль за законністю дій і рішень органів, що здійснюють досудове провадження, та засади, що реалізуються в судовому провадженні: безпосередність дослідження показань, речей і документів; гласність і відкритість судового провадження та його повне фіксування технічними засобами; змагальність сторін та свобода в поданні ними суду своїх доказів і в доведенні перед судом їх переконливості; підтримання державного обвинувачення в суді прокурором; забезпечення вільного оскарження рішеньсуду; обов'язковість рішень суду.

Отже, принципами кримінального провадження $\varepsilon$ доктринально обгрунтовані основні правові положення, які відображають предмет і метод 
кримінального процесуального регулювання, демократичну природу кримінального провадження, визначають сутність і структуру його проваджень, стадій та інститутів, спрямовують кримінальну процесуальну діяльність на досягнення завдань, поставлених державою перед кримінальним судочинством. Систему принципів крияінального провадження складають загальноправові, міжгалузеві, галузеві принципи кримінального провадження та принципи, які властиві досудовому та судовому провадженню. Система засад кримінального провадження, викладена у ст. $7 \mathrm{~K}$ ПК, потребує доповнення такими засадами, як всебічність, повнота та об'єктивність дослідження обставин кримінального провадження, незалежність та недоторканність суддів, здійснення правосуддя тільки судом та пропорційність.

\section{Література}

1. Кучннська О.П. Прннципн крнмінального провадження в механізмі забезпечення прав його учасників : монографія / О.П. Кучинсыка. - К. : Юрінком Інтер. 2013. - 288 с.

2. Великий тлумачний словник сучасної уцраїнсыкої мови / В.Т. Бусел. - К., Ірпінь:ВТФ «Перун». 2003. - $1440 \mathrm{c}$.

3. Даль В. Толковый словарь живого велицьорусского языка / В. Даль. - М., 1980. - Т. 3. - 555 с.

4. Словарь иностранных слов. - М. : Рус. яз., 1986. - 827 с.

5. Полянский Н.Н. Методика ведения семинара по уголовному процессу / Н.Н. Полянский // Социалистическая законность. - № 2. - 1952. - С. 44.

6. Галаган О.В. Поняття та система засад (принцилів) кримінального провадження / О.В. Галаган, Д.П. Пнсьменннй // Науковнй вісннк Національної академії внутрішніх справ. - № 4. - 2013. - С. 167-172.

7. Крнмінальннй процес : |підручник| / Ю.М. Грошевнй, В.Я. Тацій, А.Р. Туманянц та ін.; за ред. В.Я. Тація, Ю.М. Грошевого, О.В. Кап.іної, О.Г. Шило. - Х. : Право, 2013. - 824 с.

8. Навроцыка В.В. Засада диспозитивності та їі реалізація в кримінальному процесі України : Гмонографія] / В.В. Навроцыка. - Л. : Львівсызий держ. ун-т внутр. справ, 2010. - 440 с.

9. Нор B.T. Верховенство права як засада (принцип) кримінального провадження за новим КПК України / В.T. Нор / Актуальні проблеми кримінального права, процесу та криміналістики : матеріали IV міжн. наук.-практ. конф., присвяченої 95-річчю з дня народження проф. М.В. Салтевсыкого (м. Одеса, 2 листопада 2012 року). - Одеса, 2012. - С. 417-420.

10. Фулей Т. І. Сучасні загальнолюдські принципи права та проблеми їх впровадження в Україні : автореф. дис. на здобуття наук. ступеня канд. юрнд. наук / Т. Т. Фулей. - K., 2003. - 20 с.

11. Добровольская Т. Н. Прнниипы советского уголовного процесса (Boпросы теорин и практнки) / Т. Н. Добровольская. - М. : Юрид. лит., 1971. - 199 с.

12. Строговн4 М. С. Природа советского уголовного процесса н принцип состязательности / М.С. Строгович. - М. : Юриздат, 1939. - 251 с.

13. Строгович М.С. Курс советского уголовного процесса : в 3 т. / М.С. Строгович. - М. : Наука. 1968. - T. 1. $-470 \mathrm{c}$.

14. Михеєнко М.М. Кримінальний процес України : підручник / М.M. Михеєніко, В.Т. Нор. В.П. Шибіко. - К. : Либідь, 1992. - 413 с.

15. Громов Н. А. Принципы уголовного процесса, их понятие и система / Н.А. Громов, В.В Николайченко // Государство и право. - 1997. - JNo 7 - C. 33-40.

16. Тертишннк В.М. Кримінальний процес Українн. Загальна частнна : |підручник. Академічне вндання] / В. М. Тертишник. - K. : А.лерта, 2014. - 440 с.

17. Грнненко А. В. Принцип презумпции невиновности н его реализация в досудебном уголовном процессе / А.В. Грнненкко, Г.К. Кожевннков , С.Ф. Шумнлин. - Х. : Консум, 1997. - 97 с.

18. Тыричев И.В. Принципы советского уголовно-го процесса : [учеб. пособ.] / И. В. Тыричев. - M., 1983. $-80 \mathrm{c}$.

19. Крнмінальннй процес України : |підруч. для студ. юрнд. вншнх спец. закл. освітн| / за ред. Ю.М. Грошевого та В.М. Хотенця. - Х. : Право, 2000. - $496 \mathrm{c.}$ 
20. Кримінальний процес : [підручник] / за заг, ред. В.В. Коваленка, Л.Д. Удалової. Д.П. Письменного. - К. : «Центр учбової літератури», 2013. - 544 с.

21. Назаров В.В.Кримінальний процес України : [навч.посіб.] / В.В. Назаров, Г.М. Омельяненко. - K. : Атіка, 2008. - 584 c.

22. Лобойко Л.М. Кримінальний процес : підручник/ Л.М. Лобойко. - К. : Істина, 2014. - 432 с.

23. Грошевий К.М. Система загальних засад кримінальноьго провадження за Новим Кримінальним процесуальним кодексом України / Ю.М. Грошевий // Актуальні проблеми кримінального права, процесу та крнміналістикн: матеріали IV міжн. наук.-практ. конф., присвяченої 95-річчю з дня народження проф. М.В. Салтевсыкого (М. Одеса, 2 листопада 2012 року). - С. 315-317.

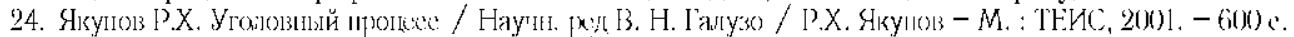

25. Колодій А.М. Принципи права України / А.М. Колодій. - К. : К)рінтом, 1998. - 208 с.

26. Оборотсв Ю.Н. Теория государства и права. Прагматический курс : Гэкзаменац. справочннк| / Ю.Н. Оборотов. - О. : Юрнд. лтра, 2005. - $184 \mathrm{c}$.

27. Нор В.Т. Всебічність, повнота і неупередженість з'ясування обставнн крнмінального провадження як його засада (принцип) / В.Т. Нор // Проблеми державотворення і захисту прав людини в У у 2 ч. - Ч.2. - Львів : Юридичний факультет Львівсыкого національного університету імені Івана Франка, 2015. - С. 246-250.

28. Козюбра M.I. Верховенство права та Україна / В.I. Козюбра // Право України. № 1-2. - 2012. - C. 30-63.

\section{А н о т а ц і я}

Aленін Ю. П., Волоицяа В. К. Поняття та система принципів кримінального провадження. - Стаття.

У статті аналізуються проблеми визначення поняття та системи принципів кримінального провадження, а також розглядасться питання щодо структури системи принципів кримінального провадження.

Kлниові слова: засади, принципи, кримінальне провадження, система, поняття, критерії принципів.

\section{Анно о а ци я}

Aления Ю. П., Восошина В. K. Понятие и система принципов уголовного производства. - Статья.

В статье анализируются проблемы определения понятия и системы принципов уголовного производства, а также рассматривается вопрос структуры системы принципов уголовного пронзводства.

Kaнцевise снова: основы, принципы, утоловное пронзводство, система, понятие, критерии принципов.

\section{S u m in a r y}

Alenin U. P., Voloshyna V. K. The concept and system of principles of criminal proceedings. - Article.

The article analyzes the problems of definition and systemn of principles of criminal proceedings, as well as addresses the structure of the system of principles of eritninal proceedings.

Key worts: basics, principles, criminal proceeding, system, notion, criteria's of the principles. 